\title{
Konsumsi ikan bersifat protektif terhadap diagnosis stroke pada orang yang pernah terdiagnosis hipertensi di Indonesia
}

Fish consumption is protective against stroke in people who have been diagnosed with hypertension in Indonesia

\author{
Arif Rahmat Kurnia1, Martalena Br. Purba², I Made Alit Gunawan ${ }^{3}$ \\ Prodi Gizi, Jurusan Ilmu Kesehatan Masyarakat, Fakultas Ilmu Keolahragaan Universitas Negeri Semarang \\ ${ }^{2}$ Instalasi Gizi Rumah Sakit Umum Pusat Dr. Sardjito \\ ${ }^{3}$ Jurusan Gizi, Politeknik Kesehatan Kementerian Kesehatan Yogyakarta
}

\begin{abstract}
Background: Stroke is a burdensome disease. The prevalence of stroke has increased by $16 \%$ over the last 6 years. The biggest risk factor for stroke is hypertension, but consumption of animal products such as meat, fish, eggs, and milk is often associated with the onset of stroke. Objective: To examine the relationship between the frequencies of animal products consumption to the incidence of stroke in 2014/2015 on hypertensive people in 2007/2008. Method: This research was using case control design performed by analyzing longitudinal data derived from Indonesian Family Life Survey (IFLS) 4 and 5 (2007/2008 and 2014/2015). The population of this study was Indonesian aged over 40 years who have been diagnosed with hypertension in IFLS 4. Results: The results of bivariate analysis using Chi Square test and Fisher's exact test found that the variables significantly associated with stroke diagnosis in IFLS 5 were IFLS 5 fish consumption ( $p=0.027$; OR=0.47); IFLS 4 milk consumption ( $p=0.04 ;$ OR=2.97); IFLS 5 hypertension diagnosis ( $p=0.006 ; O R=4.03)$; IFLS 4 diabetes mellitus diagnosis $(p=0.033 ; O R=8.91)$; and IFLS 5 diabetes mellitus diagnosis $(p=0.041 ; O R=3.73)$, also IFLS 5 physical activity $(p=0.00 ;$ OR=0.34). Conclusion: Fish consumption of 2 - 7 days per week and adequate physical activity is associated with a decreased risk of stroke in a population that has been diagnosed with hypertension. Daily milk consumption, hypertension diagnosis, and diabetes mellitus diagnosis may increase the risk of stroke.
\end{abstract}

KEY WORDS: consumption of animal products; fish consumption; hypertension; stroke

\begin{abstract}
ABSTRAK
Latar belakang: Stroke merupakan penyakit yang membebani kehidupan penderitanya. Prevalensi stroke mengalami peningkatan sebesar 16\% selama 6 tahun terakhir. Faktor risiko terbesar penyakit stroke adalah hipertensi, tetapi konsumsi produk hewani seperti daging, ikan, telur, dan susu juga seringkali dikaitkan dengan timbulnya penyakit stroke. Tujuan: Penelitian ini bertujuan untuk mengetahui hubungan frekuensi konsumsi produk hewani terhadap kejadian stroke di tahun 2014/2015 pada orang yang pernah terdiagnosis hipertensi di tahun 2007/2008. Metode: Desain penelitian kasus kontrol yang dilakukan dengan menganalisis data longitudinal yang berasal dari Indonesian Family Life Survey (IFLS 4 dan 5) tahun 2007/2008 dan 2014/2015. Populasi penelitian ini adalah penduduk Indonesia berusia di atas 40 tahun yang telah terdiagnosis hipertensi pada IFLS 4. Hasil: Hasil analisis bivariat dengan menggunakan uji Chi Square dan uji Fisher's exact menemukan bahwa variabel yang berhubungan signifikan dengan diagnosis stroke pada IFLS 5 adalah konsumsi ikan IFLS 5 ( $\mathrm{p}=0,027$; OR=0,47); konsumsi susu IFLS 4 ( $\mathrm{p}=0,043$; OR=2,97); diagnosis hipertensi IFLS $5(\mathrm{p}=0,006$; OR=4,03); diagnosis diabetes mellitus pada IFLS $4(\mathrm{p}=0,033 ;$ OR=8,91) dan IFLS 5 $(\mathrm{p}=0,041 ; \mathrm{OR}=3,73)$; serta aktivitas fisik IFLS $5(\mathrm{p}=0,002 ; \mathrm{OR}=0,34)$. Simpulan: Konsumsi ikan sebanyak $2-7$ hari per minggu dan aktivitas fisik cukup merupakan faktor protektif terhadap diagnosis stroke pada populasi yang pernah terdiagnosis hipertensi. Konsumsi susu setiap hari, diagnosis hipertensi, dan diagnosis diabetes melitus dapat meningkatkan risiko stroke.
\end{abstract}

KATA KUNCI: konsumsi produk hewani; konsumsi ikan; hipertensi; stroke

Korespondensi: Arif Rahmat Kurnia, Prodi Gizi, Jurusan Ilmu Kesehatan Masyarakat, Fakultas Ilmu Keolahragaan Universitas Negeri Semarang, Gedung F5, Kampus Sekaran, Gunungpati, Kota Semarang, Jawa Tengah, Indonesia, e-mail:arifrk@mail.unnes.ac.id, arifrahmatk@gmail.com 


\section{PENDAHULUAN}

Konsumsi produk hewani sering dicurigai sebagai penyebab munculnya berbagai penyakit kardiovaskuler seperti hipertensi dan stroke $(1,2)$. Berbagai penelitian yang sudah dilakukan memberikan hasil bervariasi terkait hipotesis tersebut. Penelitian di Tiongkok membuktikan adanya hubungan signifikan antara konsumsi daging dengan peningkatan risiko obesitas pada orang dewasa (3). Penelitian di Bogor menemukan bahwa konsumsi ikan pindang dapat menurunkan risiko terkena hipertensi (4). Analisis lanjutan yang dilakukan pada data penelitian PREMIER membuktikan bahwa konsumsi protein yang berasal dari produk hewani tidak berhubungan dengan peningkatan risiko penyakit hipertensi (5). Penelitian - penelitian tersebut masih belum menyentuh tentang dampak konsumsi produk hewani pada masyarakat yang telah mengalami hipertensi. Hal inilah yang berusaha untuk dijawab pada penelitian ini.

Beberapa pustaka menunjukkan bahwa asam lemak jenuh rantai panjang yang berasal dari daging merah, lemak babi, dan produk ternak yang berlemak tinggi dapat meningkatkan risiko penyakit kardiovaskuler (6). Data yang dihimpun oleh Pusat Kebijakan Perdagangan Dalam Negeri (7) menunjukkan bahwa konsumsi produk hewani di Indonesia terus mengalami peningkatan setiap tahun, kecuali pada produk olahan sapi. Laju penurunan konsumsi daging sapi terjadi dari tahun 1996-2011 baik di perkotaan maupun di pedesaan. Konsumsi daging ayam, susu, dan telur mengalami peningkatan sebesar 9,2\%; 9,4\%; dan 12,2\%.

Hipertensi secara umum didefinisikan sebagai kondisi persisten dari tekanan darah tinggi pada pembuluh darah arteri (8). Riskesdas 2007 menunjukkan bahwa prevalensi hipertensi berdasarkan diagnosis di Indonesia sebesar 7,2\% sedangkan berdasarkan pengukuran tekanan darah sebesar 32,2\% (9). Lebih lanjut, Riskesdas 2013 menunjukkan bahwa prevalensi hipertensi berdasarkan diagnosis meningkat menjadi 9,4\% (10). Pada tahun 2013, hanya terdapat 2 provinsi di Indonesia yang memiliki prevalensi hipertensi di bawah 20\% (11). Prevalensi stroke pada rentang waktu yang sama juga mengalami peningkatan dari $6 \%$ menjadi $7 \%$ (10).

Hipertensi merupakan faktor risiko utama stroke yang dapat dikendalikan (12-14). Stroke merupakan gangguan fungsional akut pada otak, baik secara fokal atau global yang terjadi selama lebih dari 24 jam tanpa penyebab lain kecuali gangguan vaskular. Beban akibat stroke tidak hanya menimpa pasien, tetapi juga keluarga dan orang-orang terdekat (15). Diagnosis hipertensi dapat meningkatkan risiko terkena stroke sampai dengan 8 kali lipat (16). Risiko kematian pada pasien hipertensi juga meningkat sebesar 20\% apabila terkena stroke (17). Kualitas pelayanan kesehatan yang baik telah meningkatkan jumlah survivor dari stroke sehingga jumlah orang yang menanggung beban penyakit ini pun ikut meningkat (14). Penelitian ini bertujuan untuk mengetahui hubungan antara konsumsi produk hewani dengan diagnosis stroke pada pasien yang pernah terdiagnosis hipertensi sebelumnya dengan menggunakan data Indonesia Family Life Survei (IFLS). Penggunaan data IFLS dikarenakan data tersebut dapat diakses oleh seluruh peneliti dan sejauh ini merupakan salah satu data kohort terlengkap dan cakupan terluas di Indonesia.

\section{BAHAN DAN METODE}

Penelitian ini merupakan penelitian epidemiologi analitik dengan desain retrospektif berupa kasus - kontrol dengan menggunakan data sekunder yang berasal dari Indonesia Family Life Survey (IFLS). Data IFLS yang dipakai berasal dari IFLS 4 (2007/2008) dan IFLS 5 (2014/2015) yang diunduh dari www.rand.org (18). Langkah - langkah detail mengenai metode wawancara dan pengambilan data IFLS telah dipublikasikan dalam beberapa buku petunjuk $(19,20)$.

Populasi penelitian ini adalah responden penelitian IFLS 4 dan IFLS 5 yang telah terdiagnosis hipertensi di IFLS 4. Kriteria inklusi penelitian ini adalah individu yang menjadi responden di IFLS 4 dan IFLS 5 dan terdiagnosis hipertensi pada IFLS 4. Kriteria eksklusi dari studi ini adalah individu yang berusia di bawah 40 tahun dan terdapat data tidak lengkap pada variabel-variabel yang diteliti (missing data).

Dalam penelitian ini hanya digunakan responden yang berusia di atas 40 tahun karena risiko mengalami hipertensi dan stroke meningkat seiring bertambahnya usia (21). Jumlah responden yang digunakan totalnya 
sebanyak 14.768 responden IFLS 5 yang terdiri dari 7.168 pria dan 7.600 wanita, yang merupakan lanjutan dari 14.306 responden IFLS 4 yang terdiri dari 6.672 pria dan 7.634 wanita. Data tersebut kemudian dipilih yang sesuai dengan kriteria inklusi dan dikeluarkan yang sesuai dengan kriteria eksklusi sehingga hanya tersisa sebanyak 1.285 observasi yang 69 di antaranya menderita stroke pada IFLS 5. Setelah diperoleh data responden dengan hipertensi, maka peneliti kemudian mengategorikan dalam dua kelompok yaitu kasus dan kontrol yang di match dengan usia dan jenis kelamin dengan menggunakan aplikasi STATA yang telah dilengkapi program tambahan ccmatch (22). Hasil matching dan multi stage random sampling menghasilkan 69 kontrol yang memiliki jenis kelamin dan usia yang sesuai dengan 69 kasus yang ada sehingga total observasi adalah 138 responden.

Variabel terikat pada penelitian ini adalah diagnosis stroke yang dilakukan pada IFLS 5. Variabel bebas pada penelitian ini adalah frekuensi konsumsi daging, ikan, susu, dan telur pada IFLS 4 dan 5. Variabel terkendali pada penelitian ini adalah usia dan jenis kelamin pada IFLS 4 dan 5. Variabel yang diduga sebagai pengganggu dalam penelitian ini adalah kebiasaan merokok, aktivitas fisik (dikategorikan berdasarkan lama waktu dan intensitas aktivitas fisik), obesitas sentral (diukur berdasarkan rasio lingkar pinggang dan panggul), berat badan (indeks masa tubuh $>25 \mathrm{~kg} / \mathrm{m}^{2}$ ), dan diagnosis diabetes mellitus yang diambil pada IFLS 4 dan 5. Variabel bebas diambil dalam satuan jumlah hari/minggu, tetapi peneliti juga melakukan transformasi variabel tersebut menjadi variabel binomial (mis. 0 dan 1-7, $0-1$ dan 2-7) yang kemudian disebut sebagai model $1-7$ dan dipilih yang memiliki hubungan terkuat dengan stroke.

Penelitian ini menggunakan analisis univariat berupa deskripsi dan analisis selanjutnya berupa uji t, uji Mann-Whitney, uji Fisher's exact, dan uji Chi Square yang penggunaannya disesuaikan dengan sifat masing-masing data. Analisis statistik dilakukan dengan menggunakan perangkat lunak STATA IC Ver. 13. Seluruh data diunduh dengan tipe *.dta yang diunduh dari www. rand.org. Penelitian ini telah memperoleh persetujuan etik dari Komisi Etik Fakultas Kedokteran Universitas Gadjah Mada dengan nomor KE/FK/0850/EC/2017.

\section{HASIL}

\section{Karakteristik responden penelitian}

Jumlah responden penelitian ini adalah 138 orang yang terdiri dari 69 kasus dan 69 kontrol. Jumlah responden, usia, tingkat pendidikan, kategori pengeluaran untuk konsumsi, dan diagnosis hipertensi bersifat proporsional antara kasus dan kontrol, kecuali untuk diagnosis hipertensi pada IFLS 5. Mayoritas responden berusia 40-59 tahun di IFLS 4, tetapi menjadi lebih merata pada IFLS 5. Mayoritas responden berpendidikan rendah dan memiliki kategori pengeluaran cukup dan lebih (Tabel 1).

Tabel 2 menggambarkan perbandingan diagnosis dari hipertensi, stroke, dan diabetes mellitus serta memaparkan distribusi variabel berat badan, kategori aktivitas fisik, kebiasaan merokok, dan obesitas sentral pada IFLS 4 dan 5. Tabel 3 menggambarkan tentang deskripsi statistik dari variabel konsumsi daging, konsumsi ikan, konsumsi telur, dan konsumsi susu secara numerik.

\section{Pengaruh konsumsi daging, ikan, susu, dan telur terhadap diagnosis stroke}

Analisis bivariat terhadap variabel konsumsi 4 jenis produk hewani yang bersifat numerik mayoritas menunjukkan hasil yang tidak signifikan baik pada variabel yang terdapat di IFLS 4 maupun IFLS 5 . Berikut ini adalah nilai $\mathrm{p}$ (signifikan bila nilai $\mathrm{p}<0,05$ ) dari variabel - variabel yang menggambarkan konsumsi produk hewani (nilai p ditampilkan berurutan dari IFLS 4 dan IFLS 5) yaitu konsumsi telur $(0,32 ; 0,27)$, konsumsi ikan $(0,22 ; 0,04)$, konsumsi daging $(0,78 ; 0,25)$, dan konsumsi susu $(0,49 ; 0,51)$. Hasil yang signifikan didapatkan oleh variabel konsumsi ikan pada IFLS 5 $(\mathrm{p}=0,04)$. Variabel konsumsi ikan IFLS 4 tidak memiliki angka 1 pada interval kepercayaannya sehingga odds ratio kedua variabel tersebut tidak sama dengan satu.

Hasil analisis terhadap variabel numerik yang tidak memberikan hubungan signifikan, kemudian dilakukan transformasi terhadap variabel numerik tersebut menjadi variabel kategorikal. Hasil analisis data konsumsi makanan yang telah ditransformasi menjadi variabel kategorikal dapat dilihat pada Tabel 4. Data 
Tabel 1. Karakteristik responden penelitian

\begin{tabular}{|c|c|c|c|c|}
\hline \multirow{3}{*}{ Karakteristik } & \multicolumn{4}{|c|}{ n (\%) } \\
\hline & \multicolumn{2}{|c|}{ IFLS $^{1} 4$} & \multicolumn{2}{|c|}{ IFLS 5} \\
\hline & Kasus & Kontrol & Kasus & Kontrol \\
\hline \multicolumn{5}{|l|}{ Jenis kelamin } \\
\hline Pria & $33(52)$ & $33(52)$ & $33(52)$ & $33(52)$ \\
\hline Wanita & $36(48)$ & $36(58)$ & $36(48)$ & $36(58)$ \\
\hline \multicolumn{5}{|l|}{ Usia (tahun) } \\
\hline $40-59$ & $52(75)$ & $52(75)$ & $33(48)$ & $33(48)$ \\
\hline $60-79$ & $17(25)$ & $17(25)$ & $36(52)$ & $36(52)$ \\
\hline \multicolumn{5}{|l|}{ Tingkat pendidikan } \\
\hline Rendah ( $\leq$ SMA) & $62(89)$ & $65(94)$ & $62(89)$ & $65(94)$ \\
\hline Tinggi & $7(11)$ & $4(6)$ & $7(11)$ & $4(6)$ \\
\hline \multicolumn{5}{|c|}{ Kategori pengeluaran untuk konsumsi } \\
\hline Kurang & $10(14)$ & $12(17)$ & $14(20)$ & $16(23)$ \\
\hline Cukup dan lebih & $59(85)$ & $57(83)$ & $55(80)$ & $52(77)$ \\
\hline \multicolumn{5}{|c|}{ Diagnosis hipertensi } \\
\hline $\mathrm{Ya}$ & $69(100)$ & $69(100)$ & $59(86)$ & $41(59)$ \\
\hline Tidak & $0(0)$ & $0(0)$ & $10(14)$ & $28(41)$ \\
\hline
\end{tabular}

Tabel 2. Distribusi frekuensi dan persentase dari diagnosis hipertensi, stroke, dan diabetes melitus serta variabel pengganggu penelitian

\begin{tabular}{lcccc}
\hline \multirow{2}{*}{ Variabel } & \multicolumn{2}{c}{ IFLS 4 } & \multicolumn{2}{c}{ IFLS 5 } \\
\cline { 2 - 5 } & $\mathbf{n}$ & $\mathbf{\%}$ & $\mathbf{n}$ & $\mathbf{\%}$ \\
\hline Diagnosis hipertensi & & & & \\
$\quad$ Ya & 138 & 100 & 100 & 72 \\
$\quad$ Tidak & 0 & 0 & 38 & 28 \\
Diagnosis stroke & & & & \\
$\quad$ Ya & 15 & 11 & 69 & 50 \\
$\quad$ Tidak & 123 & 89 & 69 & 50 \\
Diagnosis diabetes melitus & & & \\
$\quad$ Ya & 9 & 7 & 13 & 9 \\
$\quad$ Tidak & 129 & 93 & 125 & 91 \\
Berat badan & & & & \\
$\quad$ Normal & 78 & 57 & 77 & 56 \\
$\quad$ Berlebih & 60 & 43 & 61 & 44 \\
Aktivitas fisik & & & & \\
$\quad$ Kurang & 42 & 30 & 62 & 45 \\
$\quad$ Cukup & 96 & 70 & 76 & 55 \\
Kebiasaan merokok & & & & \\
$\quad$ Ya & 47 & 34 & 52 & 38 \\
$\quad$ Tidak & 91 & 66 & 86 & 62 \\
Obesitas sentral & & & & \\
$\quad$ Ya & 46 & 33 & 48 & 34 \\
$\quad$ Tidak & 92 & 67 & 90 & 66 \\
\hline
\end{tabular}

Tabel 3. Deskripsi statistik konsumsi daging, ikan, telur, dan susu

\begin{tabular}{ccccccc}
\hline $\begin{array}{c}\text { Konsumsi } \\
\text { (hari/ } \\
\text { mingggu) }\end{array}$ & Rerata & Median & Modus & SD & Min & Maks \\
\hline Daging & & & & & & \\
IFLS 4 & 1,56 & 1 & 0 & 1,7 & 0 & 7 \\
IFLS 5 & 1,22 & 0,5 & 0 & 1,7 & 0 & 7 \\
Ikan & & & & & & \\
$\quad$ IFLS 4 & 3,61 & 3 & 2 & 2,6 & 0 & 7 \\
$\quad$ IFLS 5 & 2,62 & 1,5 & 0 & 2,8 & 0 & 7 \\
Telur & & & & & & \\
IFLS 4 & 2,78 & 2 & 3 & 2 & 0 & 7 \\
IFLS 5 & 2 & 1 & 0 & 2,2 & 0 & 7 \\
Susu & & & & & & \\
IFLS 4 & 1,18 & 0 & 0 & 2,4 & 0 & 7 \\
IFLS 5 & 1,43 & 0 & 0 & 2,4 & 0 & 7 \\
\hline
\end{tabular}

yang ditunjukkan adalah model dari variabel-variabel tersebut yang memiliki hubungan paling kuat. Hasil yang signifikan yaitu variabel konsumsi ikan pada IFLS $5(\mathrm{p}=0,027)$ dan variabel konsumsi susu pada IFLS 4 $(p=0,043)$ (Tabel 4).

Pengaruh diagnosis hipertensi, kebiasaan merokok, aktivitas fisik, obesitas sentral, berat badan, dan diagnosis diabetes mellitus terhadap diagnosis stroke

Tabel 5 menunjukkan adanya perbedaan signifikan antara diagnosis stroke pada IFSL 4 dan IFLS 5. Selain itu, juga terdapat perbedaan signifikan antara diagnosis hipertensi pada tahun 2007/2008 dengan tahun 2014/2015. Namun demikian, tidak terdapat perbedaan antara diagnosis hipertensi pada IFLS 4 dan IFLS 5.

Variabel yang diduga sebagai pengganggu telah dianalisis secara bivariat dengan menggunakan metode Chi-Square. Diagnosis hipertensi memiliki hubungan signifikan dengan stroke yang ditunjukkan dengan $\mathrm{p}=0,006$ serta didukung dengan OR sebesar 4,03. Variabel kebiasaan merokok menunjukkan hubungan yang tidak signifikan baik pada IFLS $4(\mathrm{p}=0,59)$ maupun IFLS $5(\mathrm{p}=0,29)$. Variabel aktivitas fisik pada IFLS 4 juga tidak memiliki hubungan signifikan dengan stroke yang 
Arif Rahmat Kurnia, dkk: Konsumsi ikan bersifat protektif terhadap diagnosis stroke pada orang yang pernah terdiagnosis hipertensi di Indonesia

Tabel 4. Hubungan konsumsi daging, ikan, telur, dan susu pada IFLS 4 dan 5 dengan diagnosis stroke pada IFLS 5 (kategori)

\begin{tabular}{|c|c|c|c|c|c|c|c|}
\hline \multirow[b]{2}{*}{ Variabel } & \multicolumn{2}{|c|}{ Diagnosis stroke (n) } & \multirow[b]{2}{*}{ Total } & \multirow{2}{*}{\multicolumn{2}{|c|}{$95 \% I^{2}$}} & \multirow[b]{2}{*}{$\mathbf{p}^{3}$} & \multirow[b]{2}{*}{ OR } \\
\hline & $\begin{array}{l}\text { Kasus } \\
(\mathrm{n}=69)\end{array}$ & $\begin{array}{c}\text { Kontrol } \\
(n=69)\end{array}$ & & & & & \\
\hline \multirow{2}{*}{\multicolumn{8}{|c|}{$\begin{array}{l}\text { Konsumsi daging } \\
\text { IFLS }^{1} 4\end{array}$}} \\
\hline & & & & & & & \\
\hline $0-3$ & 57 & 63 & 120 & 0,71 & 7,63 & 0,129 & 2,21 \\
\hline $4-7$ & 12 & 6 & 18 & & & & \\
\hline \multicolumn{8}{|l|}{ IFLS 5} \\
\hline $0-2$ & 59 & 52 & 111 & 0,19 & 1,33 & 0,133 & 0,52 \\
\hline $3-7$ & 10 & 17 & 27 & & & & \\
\hline \multicolumn{8}{|l|}{ Konsumsi ikan } \\
\hline \multicolumn{8}{|l|}{ IFLS 4} \\
\hline 0 & 14 & 7 & 21 & 0,14 & 1,28 & 0,097 & 0,44 \\
\hline $1-7$ & 55 & 62 & 117 & & & & \\
\hline \multicolumn{8}{|l|}{ IFLS 5} \\
\hline $0-1$ & 41 & 28 & 69 & 0,22 & 0,97 & $0,027^{*}$ & 0,47 \\
\hline $2-7$ & 28 & 41 & 69 & & & & \\
\hline \multirow{2}{*}{\multicolumn{8}{|c|}{$\begin{array}{l}\text { Konsumsi telur } \\
\text { IFLS } 4\end{array}$}} \\
\hline & & & & & & & \\
\hline $0-1$ & 20 & 12 & 32 & 0,21 & 1,24 & 0,107 & 0,52 \\
\hline $2-7$ & 57 & 49 & 106 & & & & \\
\hline \multicolumn{8}{|l|}{ IFLS 5} \\
\hline 0 & 28 & 19 & 47 & 0,26 & 1,20 & 0,106 & 0,56 \\
\hline $1-7$ & 41 & 50 & 91 & & & & \\
\hline \multicolumn{8}{|l|}{ Konsumsi susu } \\
\hline \multicolumn{8}{|l|}{ IFLS 4} \\
\hline $0-6$ & 56 & 64 & 120 & 0,91 & 11,24 & $0,043^{*}$ & 2,97 \\
\hline 7 & 13 & 5 & 18 & & & & \\
\hline \multicolumn{8}{|l|}{ IFLS 5} \\
\hline 0 & 52 & 48 & 100 & 0,33 & 1,69 & 0,450 & 0,74 \\
\hline $1-7$ & 17 & 21 & 38 & & & & \\
\hline
\end{tabular}

dibuktikan nilai $\mathrm{p}=0,064$. Aktivitas fisik pada tahun 2014/2015 memiliki hubungan signifikan dengan stroke yang dibuktikan dengan nilai $\mathrm{p}=0,002$ dan nilai $\mathrm{OR}$ sebesar 0,34 (Tabel 5).

Keempat variabel selanjutnya yaitu obesitas sentral IFLS 4, obesitas sentral IFLS 5, indeks masa tubuh IFLS 4 , dan indeks masa tubuh IFLS 5 menunjukkan nilai $\mathrm{p}$ secara berurutan $1 ; 0,475 ; 0,086 ; 0,607$. Hal ini berarti keempat variabel tersebut tidak signifikan berhubungan dengan stroke. Dua variabel berikutnya adalah diagnosis diabetes melitus di IFLS 4 dan IFLS 5. Secara statistik kedua variabel tersebut berhubungan signifikan dengan stroke yang dibuktikan dengan nilai $\mathrm{p}$ secara berurutan sebesar 0,033 dan 0,041. Hal yang membedakan adalah nilai IK 95\% dari diagnosis diabetes melitus pada IFLS 5 yang mengandung angka 1 sehingga OR dari variabel tersebut terhadap diagnosis stroke adalah 1 sedangkan IK 95\% pada variabel yang sama di IFLS 4 tidak mengandung angka 1. Hal ini berarti OR dari variabel tersebut tidak sama dengan satu, yaitu sebesar 8,91. Kesimpulannya terdapat empat variabel confounding yang berhubungan dengan diagnosis stroke yaitu diagnosis hipertensi dan aktivitas fisik pada IFLS 5 serta diagnosis diabetes melitus pada IFLS 4 dan IFLS 5. 
Tabel 5. Hubungan antara diagnosis hipertensi pada IFLS 5, kebiasaan merokok, aktivitas fisik, obesitas sentral, indeks massa tubuh, diagnosis diabetes melitus pada IFLS 4 dan 5 dengan diagnosis stroke pada IFLS 5

\begin{tabular}{|c|c|c|c|c|c|c|c|}
\hline \multirow{2}{*}{ Variabel } & \multicolumn{2}{|c|}{ Diagnosis stroke } & \multirow{2}{*}{ Total } & \multirow{2}{*}{\multicolumn{2}{|c|}{$95 \%$ IK }} & \multirow{2}{*}{$\mathbf{p}$} & \multirow{2}{*}{ OR } \\
\hline & Kasus & Kontrol & & & & & \\
\hline \multicolumn{8}{|c|}{ Diagnosis hipertensi } \\
\hline Ya & 59 & 41 & 100 & \multirow{2}{*}{1,62} & \multirow{2}{*}{10,26} & \multirow{2}{*}{$0,006^{1 *}$} & \multirow{2}{*}{4,03} \\
\hline Tidak & 10 & 28 & 38 & & & & \\
\hline \multicolumn{8}{|c|}{ Kebiasaan merokok } \\
\hline \multicolumn{8}{|c|}{ IFLS 4} \\
\hline Ya & 22 & 25 & 47 & 0,38 & 1,77 & $0,59^{1}$ & 0,82 \\
\hline Tidak & 47 & 44 & 91 & & & & \\
\hline \multicolumn{8}{|l|}{ IFLS 5} \\
\hline Ya & 23 & 29 & 52 & 0,33 & 1,46 & $0,29^{1}$ & 0,69 \\
\hline Tidak & 46 & 40 & 86 & & & & \\
\hline \multicolumn{8}{|l|}{ Aktivitas fisik } \\
\hline \multicolumn{8}{|l|}{ IFLS 4} \\
\hline Cukup & 43 & 53 & 96 & 0,22 & 1,11 & $0,064^{1}$ & 0,50 \\
\hline Kurang & 26 & 16 & 42 & & & & \\
\hline \multicolumn{8}{|l|}{ IFLS 5} \\
\hline Cukup & 29 & 47 & 76 & 0,16 & 0,72 & $0,002^{1 *}$ & 0,34 \\
\hline Kurang & 40 & 22 & 62 & & & & \\
\hline \multicolumn{8}{|l|}{ Obesitas sentral } \\
\hline \multicolumn{8}{|l|}{ IFLS 4} \\
\hline Ya & 23 & 23 & 46 & 0,46 & 2,16 & $1^{1}$ & 1 \\
\hline Tidak & 46 & 46 & 92 & & & & \\
\hline \multicolumn{8}{|l|}{ IFLS 5} \\
\hline Ya & 22 & 26 & 48 & 0,36 & 1,66 & $0,475^{1}$ & 0,77 \\
\hline Tidak & 47 & 43 & 90 & & & & \\
\hline \multicolumn{8}{|c|}{ Indeks massa tubuh } \\
\hline \multicolumn{8}{|c|}{ IFLS 4} \\
\hline Berlebih & 35 & 25 & 60 & 0,87 & 3,79 & $0,086^{1}$ & 1,81 \\
\hline Normal & 34 & 44 & 78 & & & & \\
\hline \multicolumn{8}{|l|}{ IFLS 5} \\
\hline Berlebih & 32 & 29 & 61 & 0,40 & 1,73 & $0,607^{1}$ & 0,84 \\
\hline Normal & 40 & 37 & 77 & & & & \\
\hline \multicolumn{8}{|c|}{ Diagnosis diabetes melitus } \\
\hline \multicolumn{8}{|c|}{ IFLS 4} \\
\hline Ya & 8 & 1 & 9 & 1,12 & 401 & $0,033^{2 *}$ & 8,91 \\
\hline Tidak & 61 & 68 & 129 & & & & \\
\hline IFLS 5 & & & & & & & \\
\hline Ya & 10 & 3 & 13 & 0,89 & 21,8 & $0,041^{1 *}$ & 3,73 \\
\hline Tidak & 59 & 66 & 125 & & & & \\
\hline
\end{tabular}

Perubahan konsumsi ikan dan susu antara tahun 2007/2008 dan 2014/2015

Tabel 6 memaparkan perbandingan konsumsi ikan dan konsumsi susu pada IFLS 4 dan 5. Keempat variabel tersebut dibandingkan karena pada hasil uji Chi Square antara konsumsi ikan IFLS 5 dan konsumsi susu IFLS 4 dengan diagnosis stroke menampilkan hasil yang signifikan (Tabel 4). Perbedaan signifikan terlihat pada 
Arif Rahmat Kurnia, dkk: Konsumsi ikan bersifat protektif terhadap diagnosis stroke pada orang yang pernah terdiagnosis hipertensi di Indonesia

Tabel 6. Perbandingan konsumsi ikan dan susu pada IFLS 4 dan 5

\begin{tabular}{lccccc}
\hline Konsumsi ikan (hari/minggu) & \multicolumn{5}{c}{ IFLS 4 (2007/2008) } \\
\hline \multirow{3}{*}{ IFLS 5 (2014/2015) } & $0-1$ & 21 & 48 & 69 & p \\
& $2-7$ & 7 & 62 & 69 & $<0,001^{*}$ \\
& Total & 28 & 110 & 138 & \\
\hline Konsumsi susu (hari/minggu) & \multicolumn{5}{c}{ IFLS 5 (2014/2015) } \\
& $0-6$ & $\mathbf{0 - 6}$ & $\mathbf{7}$ & Total & p \\
\cline { 2 - 6 } IFLS 4 (2007/2008) & 7 & 107 & 13 & 120 & \\
& Total & 120 & 5 & 18 & 1 \\
\hline
\end{tabular}

* = signifikan $(\mathrm{p}<0,05)$ dengan uji Chi Square

konsumsi ikan antara data IFLS 4 dan IFLS 5, tetapi tidak terlihat pada frekuensi konsumsi susu.

\section{BAHASAN}

\section{Diagnosis ulang hipertensi merupakan faktor risiko stroke}

Diagnosis hipertensi merupakan faktor risiko stroke terbesar yang dapat diubah. Penelitian ini berusaha untuk berfokus pada pasien hipertensi dengan memasukkan diagnosis hipertensi pada IFLS 4 (2007/2008) sebagai salah satu kriteria inklusi. Rentang waktu selama 7 tahun memberikan perubahan yang cukup besar pada populasi. Perubahan ini dibuktikan dengan uji McNemar yang menghasilkan nilai $\mathrm{p}<0,001$. Analisis bivariat membuktikan bahwa responden yang terdiagnosis hipertensi pada IFLS 5 memiliki risiko 4 kali lipat mengalami stroke dibandingkan dengan yang tidak, sehingga dapat disimpulkan bahwa diagnosis ulang hipertensi dapat meningkatkan risiko terkena serangan stroke.

Kesimpulan tersebut sesuai dengan penelitian lain, bahwa penurunan tekanan darah sebesar $5 \mathrm{mmHg}$ dapat menurunkan risiko stroke sebanyak $4-7 \%$ pada pasien dengan tekanan darah diastolik di atas $140 \mathrm{mmHg}$ (23). Secara klinis, hubungan antara stroke dan hipertensi berkaitan erat dengan kondisi pembuluh darah di otak. Hipertensi terkadang dimaknai sebagai respon fisiologis untuk meningkatkan aliran darah ke otak terutama jika telah terjadi penyempitan pembuluh darah (15). Kondisi hipertensi meningkatkan tekanan pada pembuluh darah perifer sehingga terkadang bisa menimbulkan ruptur yang dapat pecah sewaktu-waktu. Ruptur pada pembuluh darah di otak dapat menyebabkan terjadinya stroke hemoragik (24).

\section{Diabetes melitus meningkatkan risiko stroke}

Diagnosis diabetes melitus tidak mengalami perubahan signifikan selama 7 tahun antara IFLS 4 dan IFLS 5. Hal ini dibuktikan dengan nilai p hasil uji McNemar yang lebih besar dari 0,05. Diagnosis diabetes melitus baik pada IFLS 4 dan IFLS 5 memiliki hubungan signifikan dengan stroke. Diabetes melitus meningkatkan risiko stroke sebesar 8,91 kali bila terdiagnosis pada IFLS 4 dan sebesar 3,73 kali bila terdiagnosis pada IFLS 5.

Diabetes melitus dikenal sebagai penyakit yang sering menimbulkan komplikasi seperti retinopati dan stroke $(25,26)$. Hubungan antara diabetes dengan stroke iskemik lebih kuat jika dibandingkan dengan hubungannya dengan stroke hemoragik, bahkan hubungan antara diabetes dengan stroke trombotik di pembuluh darah besar lebih kuat dibanding dengan stroke lakunar (27). Mekanisme patologis antara diabetes dan stroke melibatkan berbagai kondisi patofisiologis seperti disfungsi endotel pembuluh darah, kekakuan pembuluh darah, peradangan sistemik, dan penebalan membran basal pembuluh kapiler. Penelitian in vitro telah menemukan bahwa hiperglikemia akut dapat menyebabkan terjadinya penurunan fungsi sel endotel dan gangguan pada produksi nitrit oksida (NO) (27). Peningkatan inaktivasi NO atau penurunan reaktivitas otot polos terhadap NO menyebabkan adanya pelemahan 
fungsi vasodilatasi. Hal ini mengakibatkan dinding pembuluh darah menjadi kaku sehingga meningkatkan risiko aterosklerosis (28).

\section{Aktivitas fisik yang cukup dapat menurunkan risiko stroke}

Analisis bivariat berhasil menunjukan bahwa aktivitas fisik pada IFLS 4 tidak berhubungan signifikan dengan diagnosis stroke. Namun, di sisi lain aktivitas fisik pada IFLS 5 dapat menurunkan risiko terkena stroke. Perubahan ini diduga karena terjadinya pergeseran dari responden yang pada tahun 2007/2008 beraktivitas fisik cukup menurunkan aktivitasnya pada tahun 2014/2015.

Aktivitas fisik dapat membantu menjaga agar berat badan, tekanan darah, dan gula darah tetap normal (29). Aktivitas fisik dapat meningkatkan aktivitas nitrit oksida sintase yang berfungsi untuk meningkatkan kinerja endotel dan mengurangi hipertrofi bilik kiri jantung. Aktivitas fisik juga dapat menstimulasi peningkatan aktivator plasminogen pada jaringan plasma, meningkatkan konsentrasi high density lipoprotein (HDL), serta menurunkan aktivitas fibrinogen dan platelet. Kondisi aerobik saat olahraga dapat meningkatkan regulasi glukosa, menurunkan konsentrasi low density lipoprotein (LDL), trigliserida, lemak total, serta peradangan sistemik (30). Aktivitas fisik yang dilakukan oleh penderita stroke meskipun hanya sekedar berdiri dan berjalan - jalan sebentar terbukti mampu menurunkan risiko pelemahan kondisi fisik pasca serangan stroke (31).

\section{Konsumsi ikan bersifat protektif terhadap diagnosis stroke}

Konsumsi ikan berhubungan signifikan dengan diagnosis stroke bahkan sebelum ditransformasi menjadi variabel kategorik. Hanya konsumsi ikan pada IFLS 5 yang memiliki hubungan signfikan dengan diagnosis stroke. Hasil penelitian menunjukkan adanya perubahan pola konsumsi ikan pada responden di antara pengambilan data IFLS 4 dan IFLS 5. Perubahan pola konsumsi ini terjadi pada 110 responden yang pada awalnya mengonsumsi ikan sebanyak $2-7$ hari/minggu menjadi hanya sebanyak 69 responden saja di IFLS 5. Hal yang sebaliknya terjadi pada frekuensi konsumsi $0-1$ hari/ minggu yang berubah dari 28 orang pada IFLS 4 menjadi sebanyak 69 orang pada IFLS 5. Kondisi ini berbanding lurus dengan terjadinya peningkatan diagnosis stroke dari yang sebelumnya hanya sebanyak 15 orang menjadi 69 orang di IFLS 5.

Penelitian meta-analisis yang dilakukan pada penelitian - penelitian kohort yang terdapat dalam Medline dan Embase menemukan bahwa konsumsi ikan sebanyak $1-3$ kali per bulan dapat menurunkan risiko stroke iskemik sebanyak $31-35 \%$ (32). Penelitian yang dilakukan di Rumah Sakit Doris Sylvanus, Palangka Raya menemukan bahwa kurang konsumsi ikan dapat meningkatkan risiko stroke sampai 6 kali lipat (2). Kandungan omega 3 pada ikan dapat menurunkan konsentrasi trigliserida dalam darah serta mampu menurunkan proporsi LDL dan meningkatkan HDL yang dianggap sebagai salah satu alasan bahwa ikan dapat mencegah timbulnya stroke (26).

Lebih lanjut, manfaat konsumsi ikan berkurang drastis ketika proses memasaknya tidak tepat (33). Penelitian di Swedia menemukan bahwa konsumsi ikan ternyata meningkatkan risiko stroke sebesar $80 \%$ pada pria, tetapi sebaliknya menurunkan risiko stroke sampai dengan $50 \%$ pada wanita. Hal ini terjadi karena kebanyakan pria mengonsumsi ikan goreng tepung yang merupakan makanan favorit di sana. Makanan ini dibalut dengan tepung panir dan digoreng dengan menggunakan mentega atau margarin dalam jumlah yang cukup banyak (34). Kandungan asam lemak trans dan asam lemak jenuh yang terdapat dalam mentega dan margarin dapat meningkatkan risiko mengalami penyakit kardiovaskuler (34).

\section{Konsumsi susu berhubungan dengan risiko stroke}

Penelitian ini menemukan bahwa konsumsi susu pada variabel numerik tidak menunjukkan hubungan yang signifikan dengan diagnosis stroke. Setelah dilakukan transformasi pada variabel konsumsi susu menjadi data kategorik, didapatkan hubungan signifikan antara model 7 konsumsi susu pada IFLS 4 dengan diagnosis stroke pada IFLS 5. IK 95\% dari analisis tersebut mencakup angka 1 yang berarti tidak terdapat perbedaan proporsi antara kasus dan kontrol, meskipun begitu konsumsi susu tetap harus diwaspadai mengingat konsumsinya dapat 
meningkatkan risiko diagnosis stroke sampai dengan 2,97 kali lipat.

Susu merupakan kelompok makanan yang sering diduga sebagai penyebab timbulnya berbagai penyakit kardiovaskuler dikarenakan kandungan lemak jenuh dan kalsiumnya yang tinggi. Lemak jenuh telah lama diketahui sebagai salah satu faktor risiko munculnya penyakit jantung koroner dan stroke. Konsumsi kalsium dalam jumlah banyak seperti yang terdapat dalam susu dapat memicu terjadinya kalsifikasi pembuluh darah arteri dan infark miokard (35). Namun, kandungan magnesium dan potassium yang terdapat dalam susu diduga kuat juga dapat membantu melindungi jantung dan pembuluh sehingga dapat turut mencegah timbulnya stroke (36).

\section{Konsumsi daging bukan merupakan faktor risiko stroke}

Penelitian ini menemukan bahwa konsumsi daging secara total tidak berhubungan dengan diagnosis stroke. Analisis bivariat antara konsumsi daging pada IFLS 4 dan IFLS 5 baik secara numerik maupun setelah ditransformasikan, menemukan nilai $\mathrm{p}>0,05$. Hasil penelitian ini sedikit berbeda jika dibandingkan dengan beberapa penelitian sebelumnya yang meneliti pengaruh daging terhadap diagnosis stroke. Peneliti menduga hal ini terjadi karena pada penelitian ini, daging tidak dipisahkan menurut jenisnya, yaitu daging merah, daging putih, dan daging olahan. Penelitian yang dilakukan pada 13.509 perempuan di Australia menemukan bahwa konsumsi daging merah dan daging olahan memiliki risiko lebih besar untuk menderita penyakit kardiovaskuler, tetapi konsumsi daging merah atau daging olahan sendiri tidak berhubungan dengan risiko penyakit kardiovaskuler tersebut (37). Penelitian meta-analisis pada tahun 2012 menemukan hubungan antara konsumsi daging merah dengan stroke iskemik tetapi tidak berhubungan dengan stroke hemoragik (38). Penelitian meta-analisis pada tahun 2016 juga mendukung hasil penelitian tersebut yaitu konsumsi daging merah total lebih dari $50 \mathrm{~g} / \mathrm{hari}$, daging olahan lebih dari $0 \mathrm{~g}$ /hari, dan daging merah segar lebih dari $70 \mathrm{~g} /$ hari secara signifikan meningkatkan risiko mengalami stroke (39).

Hubungan daging merah dan stroke bisa terjadi akibat beberapa mekanisme yang berbeda. Daging merah diketahui memiliki kandungan lemak jenuh dan kolesterol yang tinggi sehingga mempengaruhi kadar lemak dalam darah (LDL, trigliserida, dan total kolesterol) yang dapat meningkatkan risiko terjadinya stroke (39). Daging merah kaya kandungan zat besi berbentuk heme. Zat besi merupakan metal yang dapat dengan mudah melakukan reaksi redoks sehingga mengkatalisasi pembentukan radikal bebas dalam reaksi Fenton. Dosis tinggi dari zat besi dapat mengakibatkan stres oksidatif sehingga meningkatkan terjadinya peroksidasi lemak, modifikasi protein, dan kerusakan deoxyribonucleic acid (DNA). Apabila konsumsi daging merah dilanjutkan dalam waktu lama, maka stres oksidatif tersebut dapat mengakibatkan berbagai jenis penyakit seperti diabetes tipe 2, aterosklerosis, stroke, dan peradangan kronis (38).

Lebih lanjut, daging olahan memiliki kandungan sodium tinggi yang terbukti meningkatkan tekanan darah dan pengawet berupa nitrit yang dapat memicu terjadinya kekakuan pada pembuluh darah arteri (40). Nitrit dapat memicu terjadinya aterosklerosis, disfungsi endotelial, dan menurunkan sekresi insulin. Ketiga hal tersebut dapat meningkatkan risiko stroke (39).

\section{Konsumsi telur tidak berhubungan dengan stroke}

Pada penelitian ini, hasil analisis bivariat dari variabel numerik konsumsi telur IFLS 4 dan IFLS 5 dengan diagnosis stroke menunjukkan hubungan yang tidak signifikan. Peneliti kemudian melakukan transformasi pada variabel konsumsi telur menjadi bivariat namun nilai $\mathrm{p}$ yang dihasilkan masih tidak signifikan. Telur merupakan makanan yang dikenal mengandung sumber protein yang mudah diserap tubuh dan kaya akan zat gizi seperti asam folat, vitamin B12, riboflavin, kolin, vitamin A, vitamin D, vitamin E, vitamin $\mathrm{K}$, dan asam lemak tidak jenuh. Di samping itu, telur juga mengandung $200 \mathrm{mg}$ kolesterol, yang menjadikannya sebagai salah satu sumber kolesterol tertinggi sehingga tenaga kesehatan sering melakukan pembatasan konsumsi telur pada pasien dislipidemia, hiperkolesterolemia, dan orang yang memiliki risiko penyakit kardiovaskuler (41).

Kandungan kolesterol pada makanan akan memicu terjadinya peradangan pada pembuluh darah post- 
prandial sehingga menyebabkan timbulnya stres oksidatif dan merusak fungsi endotelial. Telur juga memiliki kandungan lesitin sekitar $250 \mathrm{mg}$ yang dapat diubah menjadi trimetilamin oleh bakteri usus yang kemudian diserap oleh usus dan dioksidasi oleh liver menjadi trimetilamin N-oksida (TMAO). TMAO merupakan hasil metabolisme yang terkait dengan timbulnya aterosklerosis dan penyakit kardiovaskuler $(42,43)$.

Hubungan antara konsumsi telur dengan aterosklerosis dan penyakit kardiovaskuler telah cukup jelas, tetapi korelasi antara konsumsi telur dengan stroke masih diperdebatkan. Hal ini karena telur memiliki kandungan vitamin E, B6, B12, dan asam folat yang cukup tinggi. Kandungan folat, vitamin B12, dan B6 telah terbukti mampu meningkatkan kadar homosistein dalam darah yang dapat memperbaiki fungsi endotelial. Kandungan protein yang tinggi dalam telur diduga berkaitan dengan kemampuannya untuk menurunkan tekanan darah. Vitamin E juga dikenal sebagai antioksidan yang mampu mengurangi stres oksidatif dan menekan trombosis sehingga melindungi tubuh dari stroke (44).

\section{SIMPULAN DAN SARAN}

Konsumsi ikan sebanyak $2-7$ hari per minggu dan aktivitas fisik cukup merupakan faktor protektif terhadap diagnosis stroke pada populasi yang pernah terdiagnosis hipertensi. Konsumsi susu setiap hari, diagnosis ulang hipertensi, dan diagnosis stroke merupakan faktor risiko terhadap stroke pada populasi yang sama. Konsumsi daging dan konsumsi susu tidak berhubungan signifikan dengan diagnosis stroke terutama pada orang yang pernah terdiagnosis hipertensi.

Konsumsi ikan dapat menurunkan risiko terkena stroke sehingga promosi makan ikan harus semakin ditingkatkan. Konsumsi telur, daging, dan susu perlu disesuaikan dengan kebutuhan. Penelitian lebih lanjut dapat dilakukan untuk melihat hubungan konsumsi ikan, telur, daging, dan susu dengan diagnosis stroke terutama dalam jumlah porsi, berat, dan detail jenis makanan yang dikonsumsi dalam kelompok makanan tersebut.

\section{UCAPAN TERIMA KASIH}

Peneliti berterima kasih kepada RAND yang telah memberikan akses pada data IFLS. Penelitian ini menggunakan data IFLS yang dapat diunduh pada laman http://www.rand.org/ labor/FLS/IFLS.html.

\section{Pernyataan konflik kepentingan}

Peneliti menyatakan tidak ada konflik kepentingan dalam penelitian ini.

\section{RUJUKAN}

1. Swanida N, Malonda H, Dinarti LK, Pangastuti R. Pola makan dan konsumsi alkohol sebagai faktor risiko hipertensi pada lansia. Jurnal Gizi Klinik Indonesia 2012;8(4):202-12.

2. Perawaty, Dahlan P, Astuti H. Pola makan dan hubungannya dengan kejadian stroke di RSUD dr. Doris Sylvanus Palangka Raya. Jurnal Gizi Dan Dietetik Indonesia 2014;2(2):51-61.

3. Wang Z, Zhang B, Zhai F, Wang H, Zhang J, Du W, et al. Fatty and lean red meat consumption in China: Differential association with Chinese abdominal obesity. Nutr Metab Cardiovasc Dis 2014;24(8):869-76.

4. Wulandari RA, Madanijah S. Gaya hidup, konsumsi pangan, dan hubungannya dengan tekanan darah pada lansia anggota posbindu. Jurnal Gizi dan Pangan 2015;10(2):125-32.

5. Wang YF, Jr WY, Yu D, Champagne C, Appel LJ, Lin $\mathrm{P}$. The relationship between dietary protein intake and blood pressure: results from the PREMIER study. J Hum Hypertens 2008;22(11):745-54.

6. Tuminah S. Efek Perbedaan sumber dan struktur kimia asam lemak jenuh terhadap kesehatan. Buletin Penelitan Kesehatan 2014;38(1):1-5.

7. Pusat Kebijakan Perdagangan Dalam Negeri. Analisis dinamika konsumsi pangan masyarakat Indonesia. Jakarta: Kementerian Perdagangan RI; 2013.

8. Dorland WAN. Kamus saku kedokteran Dorland. 28th ed. Hartanto Y budi, Nirmala WK, Ardy, Setiono S, Dharmawan D, Yoavita, et al., editors. Jakarta: EGC; 2012.

9. Riyadina W, Rahajeng E. Determinan penyakit stroke. Kesmas 2013;7(7):324-30.

10. Balitbangkes. Riset kesehatan dasar 2013. Jakarta: Badan Penelitian dan Pengembangan Kesehatan Kementerian Kesehatan RI; 2013. 
11. Kementerian Kesehatan RI. Pusdatin hipertensi. Infodatin [series online] 2014 [cited 2017 Aug 21]. Available from: URL:http://www.depkes.go.id/download. php?file=download/pusdatin/infodatin/infodatin-hipertensi. pdf\&usg=AFQjCNHWLiHieCeL1Ksg4Tr_yx

12. Widimsky J. The role of arterial hypertension in the primary prevention of stroke. Cor Vasa 2016;58(2):e279-86.

13. Nidhinandana S, Ratanakorn D, Charnnarong N, Muengtaweepongsa S, Towanabut S. Blood pressure control among stroke patients in Thailand - The i-STROKE study. J Stroke Cerebrovasc Dis 2014;23(3):476-83.

14. Bushnell C, McCullough LD, Awad IA, Chireau M V, Fedder WN, Furie KL, et al. Guidelines for the prevention of stroke in women: a statement for healthcare professionals from the American Heart Association/American Stroke Association. Stroke 2014;45(5):1545-88.

15. Setyopranoto I. Stroke : gejala dan penatalaksanaan. Cermin Dunia Kedokteran 2011;38(4):247-9.

16. Usrin I, Mutiara E, Yusad Y. Pengaruh hipertensi terhadap kejadian stroke iskemik dan stroke hemoragik di ruang neurologi di Rumah Sakit Stroke Nasional (RSSN) Bukit Tinggi tahun 2011. Kebijakan, Promosi Kesehatan, dan Biostat 2013;2(2):1-9.

17. Adil MM, Beslow LA, Qureshi AI, Malik AA, Jordan LC. Hypertension is associated with increased mortality in children hospitalized with arterial ischemic stroke. Pediatr Neurol 2016;56:25-9.

18. Strauss J, Sikoki B, Witoelar F. The fifth wave of the Indonesia Family Life Survey (IFLS5): overview and field report. Vol. 1. WR-1143/1-NIA/NICHD. Santa Monica: RAND; 2016.

19. Strauss J, Witoelar F, Sikoki B, Wattie AM. The fourth wave of the Indonesia Family Life Survey (IFLS 4): overview and field report. Vol. 1. WR-675/1-NIA/NICHD. Santa Monica: RAND; 2009.

20. Strauss J, Witoelar F, Sikoki B. User's guide for the Indonesia Family Life Survey, wave 5 volume 2. Santa Monica: RAND; 2016.

21. Pang H, Han B, Fu Q, Zong Z. Association of high homocysteine levels with the risk stratification in hypertensive patients at risk of stroke. Clin Ther 2016;38(5):1184-92.

22. Cook DE. ccmatch [series online] 2015 [cited 2017 Aug 21]. Available from: URL: http://www.danielecook.com/ ccmatch/

23. Biderafsh A, Karami M, Faradmal J, Poorolajal J. Estimating the potential impact fraction of hypertension as the main risk factor of stroke: application of the distribution shift method. J Epidemiol Glob Health 2015;5(3):231-7.

24. Porth CM. Essentials of pathophysiology: concepts of altered health states. 2nd ed. Philadelphia: Lippincott Williams \& Wilkins; 2006.
25. IDF Clinical Guidelines Task Force. Global guideline for type 2 diabetes. Brussels: International Diabetes Federation; 2005.

26. Furie KL, Rost NS. Overview of secondary prevention of ischemic stroke. Kassner SE, Dashe JF, editors. [series online] 2016 [cited 2017 Aug 21]. Available from: URL: http://www.uptodate.com

27. Quinn TJ, Dawson J, Walters MR. Sugar and stroke: cerebrovascular disease and blood glucose control. Cardiovasc Ther 2011;29(6):e31-42.

28. Chen R, Ovbiagele B, Feng W. Diabetes and stroke: epidemiology, pathophysiology, pharmaceuticals and outcomes. Am J Med Sci 2016;351(4):380-6.

29. Zheng G, Chen B, Fang Q, Yi H, Lin Q, Chen L, et al. Primary prevention for risk factors of ischemic stroke with Baduanjin exercise intervention in the community elder population: study protocol for a randomized controlled trial. Trials 2014;15(1):113.

30. Gallanagh S, Quinn TJ, Alexander J, Walters MR. Physical activity in the prevention and treatment of stroke. ISRN Neurol 2011;2011:1-10.

31. Billinger SA, Arena R, Bernhardt J, Eng JJ, Ot PT, Franklin $\mathrm{BA}$, et al. Physical activity and exercise recommendations for stroke survivors: a statement for healthcare professionals from the American Heart Association/American Stroke A. Stroke 2014;45:2532-53.

32. He K, Song Y, Daviglus ML, Liu K, Van Horn L, Dyer AR, et al. Fish consumption and incidence of stroke: a metaanalysis of cohort studies. Stroke 2004;35(7):1538-42.

33. Prameswari GN. Promosi gizi terhadap sikap gemar makan ikan pada anak usia sekolah. J Health Edu 2018;3(1):1-6.

34. Wennberg M, Jansson J-H, Norberg M, Skerfving S, Strömberg U, Wiklund P-G, et al. Fish consumption and risk of stroke: a second prospective case-control study from northern Sweden. Nutr J 2016;15(1):98.

35. Boroujeni H, Saadatnia M, Shakeri F, Keshteli A, Saneei P, Esmaillzadeh A. Dairy consumption and risk of stroke: a case-control study. Int J Prev Med 2016;7(1):2.

36. de Goede J, Soedamah Muthu SS, Pan A, Gijsbers L, Geleijnse JM. Dairy consumption and risk of stroke: a systematic review and updated dose-response metaanalysis of prospective cohort studies. J Am Heart Assoc 2016;5(5):e002787.

37. Bovalino S, Charleson G, Szoeke C. The impact of red and processed meat consumption on cardiovascular disease risk in women. Nutrition 2016;32(3):349-54.

38. Kaluza J, Wolk A, Larsson SC. Red meat consumption and risk of stroke: a meta-analysis of prospective studies. Stroke 2012;43(10):2556-60.

39. Yang C, Pan L, Sun C, Xi Y, Wang L, Li D. Red meat consumption and the risk of stroke: a dose-response 
meta-analysis of prospective cohort studies. J Stroke Cerebrovasc Dis 2016;25(5):1177-86.

40. Saneei P, Saadatnia M, Shakeri F, Beykverdi M, Keshteli AH, Esmaillzadeh A. A case-control study on red meat consumption and risk of stroke among a group of Iranian adults. Public Health Nutr 2015;18(06):1084-90.

41. Chagas P, Caramori P, Galdino TP, Barcellos C da $\mathrm{S}$ de, Gomes I, Schwanke CHA. Egg consumption and coronary atherosclerotic burden. Atherosclerosis 2013;229(2):381-4.
42. Li Y, Zhou C, Zhou X, Li L. Egg consumption and risk of cardiovascular diseases and diabetes: a meta-analysis. Atherosclerosis 2013;229(2):524-30.

43. Tang WHW, Hazen SL. The contributory role of gut microbiota in cardiovascular disease. J Clin Invest 2014;124(10):4204-11.

44. Fallah-Moshkani R, Saadatnia M, Shakeri F, Keshteli AH, Saneei P, Larijani B, et al. A case-control study on egg consumption and risk of stroke among Iranian population. J Heal Popul Nutr 2017;36(1):28. 